\title{
Necrotizing soft-tissue infections in pediatric intensive care: a prospective multicenter case-series study
}

\author{
Stéphane Dauger ${ }^{1,2^{*}}\left(\mathbb{D}\right.$, Renaud Blondé ${ }^{3}$, Olivier Brissaud ${ }^{4}$, Marie-Odile Marcoux $^{5}$, François Angoulvant ${ }^{6}$, \\ Michael Levy ${ }^{1,7}$, Groupe Francophone de Réanimation et Urgences Pédiatriques (GFRUP) \\ and Réseau Mères-Enfants de la Francophonie (RMEF)
}

To the Editor,

Necrotizing soft-tissue infections (NSTIs) are severe diseases with documented high morbidity and mortality rates in adults [1]. In pediatric patients, data are scant and prospective studies extremely scarce [2]. Eneli et al. [3] reported 36 cases collected prospectively in Ontario from 2001 to 2003. The largest studies used North-American databases and exhibited the biases inherent in this methodology $[4,5]$. We designed a prospective international observational study of all severe NSTI cases seen in pediatric intensive care units (PICUs), to evaluate the outcomes and treatments.

From February 2011 to July 2016, we included consecutive patients with NSTI aged 1 month to 18 years and admitted to 33 PICUs located in high-resource countries (continental France and French overseas territories, Switzerland, Canada, and The Netherlands). Institutional review board approval (IRB-0006477) and parental consent to data recording were obtained. NSTIs are infections of any of the soft tissue layers during which tissue necrosis occurs. For this study, we defined NSTI as painful, rapidly progressive, superficial, spreading erythema

${ }^{*}$ Correspondence: stephane.dauger@aphp.fr

${ }^{1}$ Pediatric Intensive Care Unit, Assistance Publique-Hôpitaux de Paris, Service de Médecine Intensive - Réanimation Pédiatriques, Hôpital Universitaire Robert Debré, Université de Paris, 48 boulevard Sérurier, 75019 Paris, France

Full list of author information is available at the end of the article or skin necrosis, with laboratory evidence of inflammation and a fever $\left(>38.5{ }^{\circ} \mathrm{C}\right)$ or hypothermia $\left(<36{ }^{\circ} \mathrm{C}\right)$. We collected demographics; clinical, laboratory, and bacteriological data; radiological findings; and medical and surgical treatments. Descriptive data, collected without a statistical analysis plan, are reported as median [25th; 75th centiles], mean \pm SD, or $n$ (\%).

In the 50 patients included during the 4.5 -year period (Table 1), time from symptom onset to PICU admission was $2[1 ; 2]$ days. Triggers were postoperative care $(n=12 ; 24 \%)$ and trauma or animal bite $(n=11 ; 22 \%)$. Severe comorbidities included cancer $(n=10 ; 20 \%)$, varicella $(n=9 ; 18 \%)$, and preexisting chronic skin disease $(n=3 ; 6 \%)$. No predisposing factors were identified in $8(16 \%)$ patients. At diagnosis, $10(20 \%)$ patients had received non-steroidal antiinflammatory drugs, $5(10 \%)$ immunosuppressive agents, and $3(6 \%)$ glucocorticoids. Most patients had severe critical illness at admission, often with respiratory and circulatory failure, translating into high mortality prediction scores. Bacteria were recovered from 43 (86\%) patients in blood cultures $(n=16 ; 32 \%)$, skin swabs $(n=16 ; 32 \%)$, and skin biopsies $(n=4 ; 8 \%)$ (Table 2). Treatment combined respiratory support (58\%), hemodynamic support (70\%), antitoxin antibiotic (84\%), and surgery (68\%) (Table 2). Three (6\%) patients died; all had severe comorbidities (mitochondrial cytopathy, solid tumor, and leukemia). Most patients had long hospital stays. Our sample was too small to identify factors associated with surgery or mortality. original author(s) and the source, provide a link to the Creative Commons licence, and indicate if changes were made. The images or other third party material in this article are included in the article's Creative Commons licence, unless indicated otherwise in a credit line to the material. If material is not included in the article's Creative Commons licence and your intended use is not permitted by statutory regulation or exceeds the permitted use, you will need to obtain permission directly from the copyright holder. To view a copy of this licence, visit http://creativecommons.org/licenses/by/4.0/. The Creative Commons Public Domain Dedication waiver (http://creativeco mmons.org/publicdomain/zero/1.0/) applies to the data made available in this article, unless otherwise stated in a credit line to the data. 
Table 1 Characteristics of the study patients during the first $24 \mathrm{~h}$ after admission

\begin{tabular}{|c|c|}
\hline Parameters & Values \\
\hline Age (months) & $60(17.8 ; 128.5)$ \\
\hline Weight (kg) & $17.5(11 ; 42)$ \\
\hline Males/females & $21(42 \%) / 29(58 \%)$ \\
\hline In-hospital patients & $25(50 \%)$ \\
\hline \multicolumn{2}{|l|}{ Scores on admission } \\
\hline PRISM-3 (first day in PICU) & $9.5 \pm 15.9$ \\
\hline PIM-2 (first hour in PICU) & $12.6 \pm 23.3$ \\
\hline PELOD (first day in PICU) & $11.6 \pm 25.1$ \\
\hline POPC & $1.6 \pm 1.1$ \\
\hline \multicolumn{2}{|l|}{ Clinical presentation } \\
\hline Body temperature $\left({ }^{\circ} \mathrm{C}\right)$ & $38.2(37 ; 38.8)$ \\
\hline Respiratory distress & $33(66 \%)$ \\
\hline Hypotension for age & $28(56 \%)$ \\
\hline Oliguria (<1 mL/kg/h) & $14(28 \%)$ \\
\hline \multicolumn{2}{|l|}{ Main primary skin lesion } \\
\hline Erythrosis & $27(54 \%)$ \\
\hline Necrosis & $13(26 \%)$ \\
\hline Bullae & $10(20 \%)$ \\
\hline Surface (\% of total body surface) ${ }^{a}$ & $6(3 ; 10)$ \\
\hline \multicolumn{2}{|l|}{ Location } \\
\hline Legs & $13(26 \%)$ \\
\hline Arms & $12(24 \%)$ \\
\hline Head/neck & $12(24 \%)$ \\
\hline Chest/abdomen & $13(26 \%)$ \\
\hline \multicolumn{2}{|l|}{ Laboratory tests } \\
\hline White blood cells $\left(/ \mathrm{mm}^{3}\right)$ & $9610(5445 ; 18820)$ \\
\hline Hemoglobin (g/dL) & $9.7(8.9 ; 11.2)$ \\
\hline Platelets $\left(/ \mathrm{mm}^{3}\right)$ & $187500(70000 ; 305$ 250) \\
\hline $\mathrm{CRP}(\mathrm{mg} / \mathrm{L})$ & $176(85 ; 289)$ \\
\hline Fibrinogen (g/L) & $5(3.7 ; 6.5)$ \\
\hline Lactatemia (mmol/L) & $2(1.4 ; 3.8)$ \\
\hline Total proteins (g/L) & $52.5(43.8 ; 63)$ \\
\hline Urea (mmol/L) & $4(2.6 ; 5.9)$ \\
\hline Creatinine ( $\mu \mathrm{mol} / \mathrm{L})$ & $28(21 ; 57.5)$ \\
\hline
\end{tabular}

PRISM-3: Paediatric Risk of Mortality measured during the first $24 \mathrm{~h}$ after PICU admission; PIM-2: Paediatric Index of Mortality measured during the first hour after PICU admission; PELOD: Paediatric Logistic Organ Dysfunction, measured during the first $24 \mathrm{~h}$ after PICU admission; POPC: Paediatric Overall Performance Category

A few data were missing: CRP: 3, Fibrinogen: 7, Lactatemia: 1, Total proteins: 2, Urea: 1, and Creatinine: 1

a Lund and Browder chart. Data are reported as median [25th; 75th centiles], mean \pm SD, or $n(\%)$
The results of this largest prospective study of pediatric NSTIs to date confirm that this disease is rare in PICUs [2-6]. Predisposing conditions have shifted from varicella to healthcare and trauma $[2,3]$. The percentage of body surface area involved on PICU admission was consistent with studies in adults [1], whereas a major difference in absolute value was noted (about $5 \mathrm{~cm}^{2}$ in children vs. 12 $\mathrm{cm}^{2}$ in adults), which may contribute to diagnostic delays in children. MRI was rarely used to assess lesion depth. As reported by others [2,6], surgery was performed in two-thirds of patients, usually within $24 \mathrm{~h}$, and aggressive medical treatments were used. This may explain the low mortality rate, in agreement with recent data [6], despite the high predicted mortality on admission. Most NSTIs were monobacterial and many were due to Gram-positive organisms, including methicillin-resistant $S$. aureus in a few patients, as previously reported [3]. Polyvalent immunoglobulin therapy was often used, perhaps due to frequent circulatory failure suggesting toxic shock, and might also have influenced mortality rates, as suggested in a recent adult study [1]. Strong collaboration between surgeons, anesthesiologists, and pediatric intensivists should be the cornerstone of NSTI management. 
Table 2 Assessments, treatments, and course of the disease during the PICU stay

\begin{tabular}{|c|c|}
\hline Parameters & Values \\
\hline \multicolumn{2}{|l|}{ Radiological assesment } \\
\hline Ultrasound & $21(42 \%)$ \\
\hline CT scan & $22(44 \%)$ \\
\hline MRI & $7(14 \%)$ \\
\hline Identified bacteria & $43(86 \%)$ \\
\hline Only one micro-organism/two or more micro-organisms & $36(72 \%) / 7(14 \%)$ \\
\hline Gram positive & $40(91 \%)$ \\
\hline Staphylococcus aureus & $17(39 \%)$ \\
\hline Methicillin-sensitive & $15(88 \%)$ \\
\hline Panton valentine Leukocidin & $15(88 \%)$ \\
\hline Toxic shock syndrome toxin & $10(59 \%)$ \\
\hline Group A $\beta$-hemolytic Streptococcus & $14(32 \%)$ \\
\hline Gram negative & $12(25 \%)$ \\
\hline Escherichia coli & $5(11 \%)$ \\
\hline Pseudomonas aeruginosa & $4(9 \%)$ \\
\hline \multicolumn{2}{|l|}{ General treatments in the PICU } \\
\hline Mechanical ventilation/duration (days) & $29(58 \%) / 3(2 ; 3)$ \\
\hline Fluid expansion/volume (mL/kg) & $35(70 \%) / 37.5(22.8 ; 65)$ \\
\hline Vasopressors/duration (days) & $27(54 \%) / 3(2 ; 3)$ \\
\hline Morphine/duration (days) & $43(86 \%) / 5(4 ; 10.5)$ \\
\hline Benzodiazepine/duration (days) & $33(66 \%) / 5.5(2 ; 9)$ \\
\hline Transfusion of blood products & $25(50 \%)$ \\
\hline Transfusion of albumin & $25(50 \%)$ \\
\hline \multicolumn{2}{|l|}{ Specific treatments } \\
\hline Surgery/time since admission (days) & $34(68 \%) / 1(1 ; 5)$ \\
\hline One surgical procedure & $15(44 \%)$ \\
\hline Multiple surgical procedures/median per patient & $19(56 \%) / 3.5(2 ; 5)$ \\
\hline Amputation & 0 \\
\hline Antitoxin antibiotics & $42(84 \%)$ \\
\hline Immunoglobulins/doses $(\mathrm{g} / \mathrm{kg})^{\mathrm{a}}$ & $18(36 \%) / 2(2 ; 2)$ \\
\hline Hyperbaric oxygen & $5(10 \%)$ \\
\hline \multicolumn{2}{|l|}{ On PICU discharge } \\
\hline Deep thrombosis & $6(12 \%)$ \\
\hline Nosocomial infections & 12 (24\%) during 4 stays \\
\hline In-hospital death/day of death & $3(6 \%)$-D7, D9, and D13 \\
\hline POPC (without the 3 deaths) & $1.7 \pm 0.9$ \\
\hline In-PICU length of stay (days) & $12.5 \pm 14.5 ; 8(5 ; 14)$ \\
\hline In-hospital length of stay (days) & $35.6 \pm 42 ; 21(12.5 ; 41.8)$ \\
\hline
\end{tabular}

POPC: Pediatric Overall Performance Category; PICU: pediatric intensive care unit; Data are reported as median [25th; 75th centiles], mean \pm SD, or $n$ (\%)

a Immunoglobulins (1 g/kg twice in 15 patients and $1 \mathrm{~g} / \mathrm{kg}$ once in 3 patients) were started before surgery in patients with suspected toxic shock

\section{Abbreviations}

NSTI: Necrotizing soft-tissue infections; PICU: Pediatric intensive care unit; PRISM-3: Paediatric risk of mortality, measured during the first $24 \mathrm{~h}$ after PICU admission; PIM-2: Paediatric index of mortality, measured during the first hour after PICU admission; PELOD: Paediatric logistic organ dysfunction, measured during the first $24 \mathrm{~h}$ after PICU admission; POPC: Pediatric overall performance category.

\section{Acknowledgements}

We thank Jérôme Grasset, IRISEO, Saint-Victurnien, France, for his invaluable help in designing, building, and monitoring the SCIPIC database.

\section{Collaborators who included patients:}

Laurent Balu, MD, CHU Félix Guyon, Saint-Denis de la Réunion, France (GFRUP). Marc-André Dugas, MD, CHU de Québec, Canada (RMEF). Hélène Gatti, MD, 
Centre Hospitalier de Polynésie Française, Papeete, Tahiti, France (GFRUP) Etienne Javouhey, MD, PhD, Hôpital Femmes-Mères-Enfants, HCL, LyonBron, France (GFRUP, RMEF). Nicolas Joram, MD, Hôpital mères-enfants, CHU Nantes, France (GFRUP, RMEF). Joris Lemson, MD, Radboud University Medical Centre, Nijmegen, The Netherlands. Fabrice Lesage, MD, Hôpital Universitaire Necker Enfants malades, Paris, France (GFRUP, RMEF). Christophe Milesi, MD, CHU Arnaud de Villeneuve, Montpellier, France (GFRUP). Marie-Hélène Perez, MD, Centre Hospitalier Universitaire Vaudois, Lausanne, Switzerland (GFRUP). Isabelle Wroblewski, MD, Hôpital Nord La Tronche, CHU Grenoble, France (GFRUP).

\section{List of the 33 participating centers:}

France: Dupuytren University Hospital, Limoges; Jean Minjoz University Hospital, Besançon; Pellegrin University Hospital, Bordeaux; Côte de Nacre University Hospital, Caen; Estaing University Hospital, Clermont-Ferrand; Raymond Poincarré University Hospital, Garches; Grenoble-Alpes University Hospital Grenoble; Jeanne de Flandres University Hospital, Lille; Femme-MèreEnfant University Hospital, Lyon-Bron; La Timone University Hospital, Marseille; Marseille Nord University Hospital, Marseille; Nancy-Brabois University Hospital, Vandoeuvre-les-Nancy; Mère-Enfants University Hospital, Nantes; Lenval University Hospital, Nice; Robert Debré University Hospital, Paris; NeckerEnfants malades University Hospital, AP-HP, Paris; Armand-Trousseau University Hospital, AP-HP, Paris; American Memorial University Hospital, Reims; CharlesNicolles University Hospital, Rouen; University Hospital, Saint-Etienne; University Hospitals, Strasbourg; Mères-Enfants University Hospital, Toulouse; Gatien de Clocheville University Hospital, Tours; Arnaud de Villeneuve University Hospital, Montpellier; Mamoudzou Hospital, Mayotte; Felix Guyon University Hospital, Saint-Denis, La Réunion; Mamao Hospital, Papeete, Tahiti. Switzerland: Lausanne University Hospital, Lausanne. Québec (Canada): Laval University Hospital, Québec; Sainte-Justine University Hospital, Montréal; Fleurimont University Hospital, Sherbrooke. The Netherlands: Wilhelmina Children's University Hospital, Utrecht; Rabdoud University Hospital, Nijmegen.

\section{Authors' contributions}

SD and RB had full access to all the data in the study and takes responsibility for the integrity of the data and the accuracy of the data analysis. RB served as co-investigator for this study. Concept and design: SD, RB. Acquisition: all authors. Analysis and interpretation of data: SD, RB, FA, ML. Drafting of the manuscript: SD, FA, ML. Critical revision of the manuscript for important intellectual content: All authors. Statistical analysis: FA. Obtained funding: SD, RB. Administrative, technical, or material support: SD, RB. Supervision: SD, RB, FA, ML. All authors read and approved the final manuscript.

\section{Funding}

This work was supported by the Réseau Mère Enfants de la Francophonie (RMEF) with a Grant of 7000 \$CA. The funder had no role in the design and conduct of the study, collection, management, analysis, and interpretation of the data, preparation, review, or approval of the manuscript, and decision to submit the manuscript for publication.

\section{Availability of data and materials}

The datasets used and/or analysed during the current study are available from the corresponding author on reasonnable request.

\section{Declarations}

Ethics approval and consent to participate

The study was approved by Robert-Debré Hospital International Review Board (IRB-0006477) and parental or legal guardian consent was obtained.

\section{Consent for publication}

Not applicable.

\section{Competing interests}

The authors declare that they have no competing interests.

\section{Author details}

${ }_{1}^{1}$ Pediatric Intensive Care Unit, Assistance Publique-Hôpitaux de Paris, Service de Médecine Intensive - Réanimation Pédiatriques, Hôpital Universitaire Robert Debré, Université de Paris, 48 boulevard Sérurier, 75019 Paris, France. ${ }^{2}$ Université de Paris, NeuroDiderot, INSERM UMR 1141, 75019 Paris, France.

${ }^{3}$ Adult and Pediatric Intensive Care Unit, Centre Hospitalier de Mayotte, 97600 Mamoudzou, France. ${ }^{4}$ Pediatric Intensive Care Unit, Hôpital Universitaire Pellegrin, Université de Bordeaux, 33000 Bordeaux, France. ${ }^{5}$ Pediatric Intensive Care Unit, Hôpital Universitaire Purpan, Université de Toulouse, 31000 Toulouse, France. ${ }^{6}$ Pediatric Emergency Department, Assistance Publique-Hôpitaux de Paris, Hôpital Universitaire Necker-Enfants Malades, Université de Paris, 75005 Paris, France. ${ }^{7}$ Institut Pasteur, Invasive Bacterial Infection Unit, 75724 Paris, France.

Received: 22 February 2021 Accepted: 31 March 2021

Published online: 12 April 2021

\section{References}

1. Madsen MB, Skrede S, Perner A, et al. Patient's characteristics and outcomes in necrotising soft-tissue infections: results from a Scandinavian, multicentre, prospective cohort study. Intensive Care Med. 2019:45:1241-51.

2. Schröder A, Gerin A, Firth GB, Hoffmann KS, Grieve A, Oetzmann von Sochaczewski C. A systematic review of necrotising fasciitis in children from its first description in 1930 to 2018. BMC Infect Dis. 2019:19:317-29.

3. Eneli I, Davies HD. Epidemiology and outcome of necrotizing fasciitis in children: an active surveillance study of the Canadian Paediatric Surveillance Program. J Pediatr. 2007;151:79-84.

4. Totapally BR. Epidemiology and outcomes of hospitalized children with necrotizing soft-tissue infections. Pediatr Infect Dis J. 2017;36:641-4.

5. Endorf FW, Garrison MM, Klein MB, Richardson A, Rivara FP. Characteristics, therapies, and outcome of children with necrotizing soft tissue infections. Pediatr Infect Dis J. 2012;31:221-3.

6. Zundel S, Lemaréchal A, Kaiser P, Szavay P. Diagnosis and treatment of pediatric necrotizing fasciitis: a systematic review of the literature. Eur J Pediatr Surg. 2017;27:127-37.

\section{Publisher's Note}

Springer Nature remains neutral with regard to jurisdictional claims in published maps and institutional affiliations.
Ready to submit your research? Choose BMC and benefit from:

- fast, convenient online submission

- thorough peer review by experienced researchers in your field

- rapid publication on acceptance

- support for research data, including large and complex data types

- gold Open Access which fosters wider collaboration and increased citations

- maximum visibility for your research: over 100M website views per year

At BMC, research is always in progress.

Learn more biomedcentral.com/submissions 